\title{
Confronting Plausible Simplicities and Bridging the Tragic Chasm: Bernard Crick's Political Journalism Reconsidered
}

\author{
Charlie Ellis $^{1}$ \\ Accepted: 19 November 2021 / Published online: 19 January 2022 \\ (c) The Author(s), under exclusive licence to Springer Science+Business Media, LLC, part of Springer Nature 2021
}

\begin{abstract}
The world of political comment is often considered to be lacking in nuance and sophistication, dominated by immoderate polemicists. This connects to wider debates concerning knowledge and expertise in a liberal democracy, which the COVID19 pandemic has brought to the fore. The article examines the contribution made to the debate concerning political comment by the British academic, political theorist and journalist Bernard Crick. Crick had a low opinion of much political comment which he believed provided a breeding ground for populist sentiment. For Crick, it was a duty of academics to contribute to the opinion space and elevate the standard of public discourse. The seriousness with which Crick took political journalism was a recognition of the important role it plays in the transmission of political ideas, one often underappreciated by academics. This article looks at Crick's own contribution as a frequent political commentator in the British press and how this connected with his moderate political stance and his conception of political activity. It argues that the example that Crick sets is, despite the very different media and academic landscape he operated in, worth emulating.
\end{abstract}

Keywords Moderation $\cdot$ Political discourse $\cdot$ Intellectuals $\cdot$ Media $\cdot$ Academia $\cdot$ Opinion

'Who reads the newspapers for political thought?' (Crick 1981)

It is widely alleged that political discourse has degenerated into a series of hyper-partisan, 'ideological food fights' (Sandel 2012) lacking an appreciation of the nuances that ought to be involved in all political and cultural controversies. Many allege that the 'commentariat' are partly to blame for this and that they consequently do a disservice to our political culture. At a time when former political commentators Boris Johnson and Michael Gove are at the summit of UK politics, the influence of the 'commentariat' seems stronger than ever. As Jacobs and Townsley (2011) outline, the last 30 years or so have seen an expanding 'opinion space', with political talk shows giving political commentators an even higher prominence. Underlying concerns about the impact of the commentariat is the wider debate about the role of the media and intellectuals in fostering a healthy political realm (Gamble 2004a; Jacobs and Townsley 2011; Lloyd 2004). Such concerns also highlight the role of commentators in transmitting ideas and information between the

Charlie Ellis

charliejellis@gmail.com

1 Edinburgh, UK political and academic elites and a wider informed public (Turner 2001). Ultimately, what lies behind this are debates concerning knowledge and the role of experts and expertise in a liberal democracy, something which the COVID-19 pandemic has exposed (Lavazza \& Farina 2020; Gellner 1990).

The acclaimed political theorist and writer Bernard Crick (1929-2008) offers an illuminating perspective on the place of political commentary in the democratic public sphere. Crick repeatedly bemoaned the cynicism of the media and the low quality of political discourse (Crick 2000b). He believed that the 'plausible simplicities' of populist politicians and commentators had successfully 'debased the level of public debate' (Crick 2005). Writing in The Guardian in 1992, he wrote that 'the complexity of social problems is hard to grasp and convey among the diurnal galloping myopia from which even the broadsheets now suffer incurably, let alone the papers that Middle England reads'. As a consequence, politicians were tempted into 'ever greater simplification and sloganising' (Crick 1992b). In short, Crick saw the character of the commentariat as a significant obstacle to creating a healthier politics. Given the significant expansion of the opinion space in recent decades, this obstacle has only grown since Crick's death. As Small $(2002,2)$ relates, Crick's critique echoes similar 'jeremiads' 
bemoaning a decline in 'the public life of the mind' by other public intellectuals, such as Crick's friend Richard Hoggart (2004; Crick 2000b). Crick's criticisms are also, on the face of them, the sort of disparagement of the commentariat typical in academic circles. Many academics use quotations from political commentators to spice up a paper or conference presentation and to illustrate the muddled, simplistic thinking that-it is believed-pervades the public sphere. From this perspective, the commentariat, by its nature, is simplistic and corrosive of politics.

This was not Crick's view. Despite his harsh criticisms of political commentary, Crick was himself, in addition to his significant contribution to academic political studies, a fluent and prolific commentator on politics in the broadsheet press and a self-confessed 'polemicist'. Crick also appeared regularly on TV and radio and could be considered something of a media don (Ferguson 1999; Collini 2006) and media intellectual. Political and social commentators such as Yasmin Alibhai-Brown of the Independent and Joyce McMillan of the Scotsman were among Crick's friends. Crick seemed to thrive in the immediacy of the world of newspaper comment. While it is fairly common for academics to contribute to the comment pages and the media more generally, Crick did it far more than most. It is something he almost did by impulse. Crick would regularly send sharp letters to editors, responding to inaccuracies and exaggerations contained in articles they had published. It is easy to imagine him being very active and disputatious on Twitter - and his name trending with regularity, particularly on the themes of multiculturalism, sovereignty and university politics. As Blunkett (2012) relates, Crick was often 'deliberately provocative' and pieces with titles such as 'To Hell with 'the Students"' (Crick 1969) and 'The growing threat from Scotland' (Crick 1990a) look like classic clickbait!

In recent years, Crick's classic In Defence of Politics (Crick 1962, 1982a) has again risen to prominence. The thoroughgoing critique of populism, central to much of his political writing, has given his work a sharp relevance in the era of Trump, Bolsonaro, Modi, Orban, et al. Though aspects of In Defence of Politics are undoubtedly dated, the core of Crick's account of political activity remains persuasive. Crick's account has strongly influenced recent attempts to defend politics against various adversaries (Stoker 2006; Flinders 2012; Gamble 2019). His significant contribution to political theory (Hampsher-Monk, 1993) and British political studies has been recognised (Kenny 2006; Grant 2010; Jeffrey 2009), as has his role in parliamentary reform, the promotion of citizenship education (Blunkett 2012) and his conflict resolution work in Northern Ireland (Taylor 1993; Walker 2017), South Africa and elsewhere. This article looks at another side of Crick-Crick the commentator and polemicist. It argues that his journalism was not a sideline or adjunct to his academic career, but instead a key element of Crick the public intellectual. Through examining his journalism, we can gain a richer understanding of his thinking.
What emerges are his identifiably social democratic outlook and an overriding belief in political activity as a vital but not dominating part of human life. We will also find much of great relevance to a range of still smouldering debates.

This article focuses on the way that Crick's work as a political commentator challenges two common preconceptions about the world of comment: (i) as a self-described 'moderate', Crick's journalism challenges the idea that political commentary is an arena where committed ideologues can best thrive; (ii) more fundamentally Crick's political journalism challenges the view that the world of political commentary is inherently simplistic and lacking in nuance and, as a consequence, inimical to the values of academia. Rather than steering clear, academics should involve themselves in the sphere of political commentary. He passionately desired that the 'tragic chasm between academic and practical political thinking' (Crick in Ball 2015, 446) be bridged. I will conclude by examining another aspect to this tragic chasm. The seriousness with which Crick took his political journalism was a recognition of the important role it plays in the transmission of political ideas. Academics have, I suggest, for too long tended to underappreciate the degree of influence wielded by polemical commentators. Those seeking to contribute to social and political change, as so many academics wish to, ought to take political comment more seriously. In detailing these arguments, I will focus on five themes covered in Crick's comment pieces:

- His advocacy for academics to contribute to public debate and elevate public discourse.

- Crick's role as a political moderate-in defence of compromise and his active role in conflict resolution and how this involvement elevated his political commentary.

- His significant contribution to debates about the Labour Party social democracy in the UK. This contribution was part of a life-long involvement in Labour politics-his commentary sought to influence the party's thinking and policies.

- His close involvement in debates on devolution and his foresightedness about Scottish independence and the possible break-up of the UK.

- Crick's forthright commentary on university politics and his critique of student radicalism, which has relevance to contemporary debates about free speech.

It is a tribute to the range of topics Crick covered that this represents only a percentage of the subjects he intervened in with his journalism. While fairly wide-ranging, his journalism coalesces around a desire to demonstrate the true character of political activity and a rejection of plausible simplicities. His sceptical tone makes his pieces refreshing in a genre often dominated by exaggeration and pessimistic 'endism' ('the death of culture', 'suicide of Europe', 'the abolition of Britain' etc.). In his journalism, Crick consistently critiqued the overheated rhetoric employed by politicians and political commentators, 
which he saw as corrosive. However, his response was spirited engagement and not lofty dismissal.

\section{A Transient Art?}

Crick's work appeared in a variety of newspapers including the Guardian, Observer, Independent, and Evening Standard. After moving to Scotland (in 1984), he became a regular in the pages of the Scotsman and Herald. Crick 'confessed' to enjoying writing his fortnightly column for the Scotsman 'more than anything I have done since In Defence of Politics' (Crick 1990c, viii). He also produced articles for New Society, New Statesman and other similar journals. He contributed to both Marxism Today and the Spectator, again exemplifying his pluralistic conception of politics. In addition, he wrote many editorials for Political Quarterly (Ball 2015) and also a regular column on theatre during the 1970s in the Times Higher Education Supplement. Political Quarterly and the Times Higher were ideal settings for his pieces given his passionate desire to bridge the divide between academia and the contested notion (Collini 2006) of the general educated reader (Crick 1992b, 1995a). Crick published five volumes of essays and longer newspaper pieces during his lifetime. His many Political Quarterly articles and editorials have now been collected (Ball 2015), but most of his journalism has not. If you tried to collect all his journalism together, it would produce several more substantial tomes. What value are his articles beyond those interested in the particularities of Crick's life and career?

Two prominent twentieth century polemicists offer differing perspectives on the long-term value of journalistic comment. Malcolm Muggeridge (1966, 7-8) posited that '[s] urely the glory of journalism is its transience' and that 'only the greatest bores' could imagine that 'their offerings reach beyond the last edition'. In contrast, Kingsley Amis (1977, 9) is surely correct to suggest that the press and political journals constitute a 'valuable quarry for anyone in search of the nuances and overtones, as well as the major currents, of a historical period'. Crick himself accepted that because 'speculative' pieces for a 'general thinking audience' are written close to events; they 'can date and become obscure'. However, these pieces should be judged primarily by whether they 'can provoke thought' and not by 'any claims to be definitive on some hard and lasting narrow ground' (Crick 1988a, 1988b, 60). Crick's decades-old pieces certainly still provoke. They also emphasise the value of commentary born of knowledge and experience. In this, they are consistent with Crick's entire career which saw theory and practice interlocked. Crucially, the topics he wrote articles about were all ones he was intimately involved in. He was not, as some intellectuals have done, simply carrying cultural capital from one sphere to another (Collini 2006), and idly pontificating on subjects outside his areas of expertise.

Crick's journalism rehearsed and reworked themes found in his more extended writings. There is a large degree, as he admitted, of 'self plagiary' (Crick 1968a, xii) to his journalism. While examining Crick's writings, I have often had a sense of déjà vu. As Ball (2015) relates, a number of favourite phrases, allusions and quotations recur throughout his work. This is particularly true of his Political Quarterly pieces and his journalism. It demonstrates that many of his pieces were produced quickly. However, some of this repetition found between his journalism and his more scholarly work can be seen as an example of what Flinders (2013) calls 'triple writing'. Namely, writing broadly the same article for a different audience, with different degrees of scholarly apparatus. In the final stage, 'the research forms the focus of a number of succinct, pithy and even controversial articles for newspapers, magazines or popular websites'. This third stage is something Crick was particularly adept at. Crick's immodest claim that he could 'write better than nearly all social scientists' (Crick 1989b, 119) is given some substantiation by his journalism though; as Ball (2015, 35-37) suggests, Crick's own writing style did not always meet his expressed preference for 'plain-speaking'.

Was his time spent writing opinion pieces time well spent? Jeffrey (2009) suggests that Crick may have been 'over productive' in the latter part of his career, given all his essay writing and journalism. From this perspective, his career could be divided into two: an early period of influential scholarship and a second a period of 'impact', through his constitutional and citizenship work, his work on Orwell and his journalism. Jeffrey ultimately rejects such a divide, seeing them as part of the same life project, of articulating the practice of politics and promoting the citizenship education necessary for a successful politics. Crick's column writing was an area of continuity, something he did throughout his career. He began writing regularly for the national press when the Observer editor David Astor began employing him in the 1960s (Kingston 1996). This emphasises the prominent position he had already achieved within his field by that stage, which gave him a public profile and a pulpit for his ideas.

This raises the question of whether an academic of his standing would today be prepared to spend so much time in the world of comment? If they did, would they might lose credibility in a sphere where the adjective 'journalistic' is often used as a term of criticism, implying a lack of rigour. The historian Niall Ferguson wrote pseudonymously for the Telegraph and Mail for several years fearing his academic work might be 'discredited' were his academic peers to find out (Ferguson 1999, 208). As Collini (2006, 379) remarks, figures such as A. J. P. Taylor exemplified some of the 'tensions' between a 'dual life as academic scholar and popular journalist'. However, in Crick's case he took his 
contributions to the press seriously-it was not the rushed 'hack work' Taylor often produced.

Crick was often concerned that he had spent too much time writing 'casual journalism'. He noted (in 1973) that in the 10 years since writing In Defence of Politics, he had not written 'any worthwhile book in political theory' (Crick 1973, ix). Indeed, this would be something of a theme of his career. In 1974, he related that he had 'nearly finished' a work on American political thought before the 'renewal of American radicalism' in the 1960s undermined some of the key arguments of his text (Hennessy 1974). Many of the dust jackets of his books would contain some reference to 'he is currently preparing a book on'... but the book would not appear and instead the themes would be written up in essays and journalism. Most infamously, his much mentioned book on the Four Nations of the UK that he was working on for the last 25 years of his life never will appear. Ball $(2015,35)$ is surely correct in saying that Crick was 'essentially an essayist, not someone who was happiest writing at great length'.

\section{Bridging the Tragic Chasm}

As well as his profusion of articles, Crick also contributed to the debate about the world of political comment. Crick, writing in 2000, argued that serious political writing for the general educated reader had migrated from the book or pamphlet to the opinion pages, and that we live in 'the great age of the political column' (Crick 2001, 102). Certainly, there has been a great increase in the numbers of political commentators in recent decades (Lloyd 2004). Crick believed that political commentators have played a significant role in promoting highly influential 'plausible simplicities' about British society. Crick was keen to disabuse his fellow academics of the notion that such simplifications were inherent to the genre and wished to draw more of his colleagues to this world. He believed that it was a duty of academics to play an active role in political debate rather than leaving it to the professional controversialists. He sought to promote political commentary which provided perspective and greater analytical muscle. When analysing the Observer in 1985, he praised the writing of their commentators Alan Watkins and Bernard Levin who regularly produced 'quirky or forceful' pieces. However, there was a lack of depth to their work which seemed to be written 'from the top of their heads' with little research involved (Crick 1989b, 108). Crick was a polemicist who argued for a better standard of polemics. He believed that contemporary polemicists and academics tended to give political writing a bad name. Though fluent and punchy, most political commentators lacked depth of insight, while most academics seemed incapable of communicating their ideas in a straightforward way, in clear language. What he hoped for was that the audience would be exposed to a better standard of political writing. Academics should not leave it to the immoderate, fulminating commentators. As he puts it, 'journalism is too important to be left to the journalists' (Crick 1990c,vii).

By his final decades, Crick was, as Gamble (2004b) puts it, 'deeply out of sympathy with the modern university'. However, though he would have rejected the audit culture and the rise of 'the tyranny of impact' (Flinders 2013), Crick would have been successful in such a climate, able to produce high quality books and papers which made an 'impact' beyond academia. A key theme of his biography of Orwell was promoting Orwell the political essayist (Crick 1980). Crick's desire to see better political writing was behind his establishment of the The Orwell Prize (Gamble 2004a). This aimed to encourage good political writing informed by academic insights but not suffocated by the 'internalised dialogues of the ivory tower' (Crick 1990c, viii). Reviewing an academic book on Unionism in Northern Ireland, Crick commented that, because of its academic language, 'the people who should read this book will, unhappily, find it incomprehensible' (Crick 2001, 143). In short, fantastic academic work was not having the impact it should in terms of informing public debate. This exasperation with impenetrable academic discourse would become an increasingly common theme of his essays and journalism (Crick 1995a, 1992b). Many criticisms of academia can come across as a philistine and populist rejection of university education. This was not Crick's position. He believed that excellent and important work was being done in the field of political studies but they were failing in what Flinders (2013) terms the 'art of translation'. They were failing to 'promote the findings and benefits of the discipline beyond academe'. Crick spent his career trying to make an impact and his journalism was central to this. As Seyd (2008) has remarked, in his journalism (and radio and TV appearances) Crick was 'always trying to engage with a broad citizenry', combining 'academic rigour' with his 'combative' streak.

\section{The Truculent Moderate}

The idea of a moderate political commentator seems something of a contradiction in terms. Most of the commentariat are renowned for their uncompromising positions and the vehemence of their rhetoric. In our current media, centrist contrarians such as the Times triumvirate of David Aaronovitch, Daniel Finkelstein and Matthew Parris are fairly rare exceptions. The Orwell Prize winning Aaronovitch describes himself as a radical moderate and admits that this is a difficult position to hold in an era of polarisation. The rise of social media has seemingly intensified the overwhelmingly partisan character of political commentary and led to the ‘footballification' of political debate (O'Brien 2020). 
Intellectual activity might be considered essentially 'moderate' in its faith in rationality, measured discourse and disinterestedness. In contrast, many of the most prominent 'political intellectuals' tend towards immoderate attitudes and discourse. Some fear that modern politics is dominated by an opinionated 'commentariat' who have replaced analysis by comment and that such trends have been intensified by the rise of think tanks 'viewspapers', social media and politicised news. This has all served to enlarge the 'opinion space' in our media (Jacobs and Townsley 2011; D'Ancona 2017; Flinders 2012). In such a climate, the voice of the 'moderate' political intellectual is likely to be overlooked; unloved by those on the same 'side' and lacking the combative qualities required in a media-driven age. Is the notion of a 'moderate' political intellectual a contradiction in terms, or are they in fact an essential ingredient of a healthy polity?

In a highly engaging interview with the historian Peter Hennessey, the author contrasted Crick's moderate politics with his contribution as a 'pungent polemicist'. He concluded that Crick was deserving of 'that most paradoxical if expressive of political labels', an 'extremist of the centre' or 'truculent moderate' (Hennessy 1974). Often moderates are criticized for sitting on the fence and lacking conviction. As Smith and Holmwood (2013) outline in their volume on the theme, moderation 'has a tendency to be defined by a sense of what it is not' and by 'its apparent absence of ideology'. Crick certainly did not lack conviction or a clear worldview. He had, 'a irascible way of seeing things' (Annan 1981) and, as Gamble notes, 'fierce views about most political subjects' (Gamble 2008). Crick certainly did not call for academics to be political eunuchs, though did stress that they should not be 'self-indulgent and exploitative of their position' (Crick 2000a, 41).

One sphere where moderates are praised is in conflict zones. In these, they have often played a vital role in overcoming deep-seated social and political divisions and rebuilding post-conflict societies. Crick wrote several articles on the conflicts in South Africa and Northern Ireland. These are often cited as conflicts in which the possibility of a full civil war was genuine. Following Arendt, Crick saw violence as 'the breakdown of political power, not its extension' (Crick 1982b). These conflicts were brought to an end through political negotiation. If we were looking for evidence to defend politics as a noble art, the transformation of these two countries might well be the first to be cited.

Unlike many comment pieces on such themes, Crick's articles on South Africa utilised not only his political expertise but also the knowledge acquired when visiting the country. This he did while accompanying his son Tom in his dispute resolution work with The Carter Center. Underlying this was Crick's understanding of political activity as the creative conciliation of differing interests. So not only was he adding some academic detachment (by pointing out obvious fallacies and oversimplifications being promoted) but also knowledge and insight gained from a genuine engagement. In such cases, he believed that moderates were actually fairly marginal to making progress. In other words, apartheid would not end just because white South African liberals denounced it. What was required were meaningful negotiations to occur between the ANC and the National Party government.

Though moderates were somewhat marginal, moderation was critical. One of the key prerequisites for successful peace negotiations was when both sides realised that 'total victory' for their point of view was impossible. Of course, some would not accept that total victory was not still possible. Crick saw the violence 'spasms' of 1991 not as something to despair of but a sign that there existed genuine 'political progress' that extremists wished to disrupt (Crick 1991). In the same way, he felt that the bombing campaigns by the 'Real IRA' illustrated that genuine progress was being made. What was needed was time to 'accustom party activists to the necessity of compromise'. As a consequence things would 'appear to get worse before they get better' due to the 'fanatic irreconcilables in both camps beyond all political reason' who would 'set out to wreck negotiations'. Ultimately, the efforts of the fanatics were 'actually a sign that real movement, however slow it must be, is afoot' (Crick 1997).

Crick understood that the rhetoric deployed by the political leaders in these situations was often at odds with the negotiations going on. Reflecting on the situation in Northern Ireland in 1995, he remarked that Unionist leaders had to 'sound intransigent' until their 'followers get used to the idea of unknown compromises to come through necessarily prolonged and genuine negotiations'. The same was, Crick believed, true of the Sinn Fein leadership (Crick 1995b). Crick himself acted as a facilitator in some of the talks in Northern Ireland. (Walker 2017; Blunkett 2012). Taylor (1993, 194-195) recalls Crick leading a Sheffield University trip to Belfast in 1970. Throughout the trip, 'potentially angry and bitter' sessions were 'gently steered back' by Crick. So, in both of these conflict zones Crick was very much prepared to get stuck in, believing that this was what anyone with a true faith in politics must do. This meant that, in the cases of South Africa and Northern Ireland, his commentary was born of genuine engagement with the issues.

\section{Labour Pluralist}

The most common theme for Crick's journalism was the Labour Party and social democracy in the UK. Moderates are often considered unprincipled centrists, uninterested in making genuine political and social change. This clearly is not true in Crick's case, as his relationship with Labour politics demonstrates. Having joined the party at the age of 
16, Crick generally remained loyal to the party, even when despairing at some of the turns it took (Crick 1996). What is significant is that, from an early age, he saw party politics as a route to political change. In his support for Labour, he was aware that combining this with his role as an academic thinker was not easy. He outlined that 'any theorist supporting a political party must either be honest and self-critical or appear as silly as an election broadcast' (Crick 1974a).

Writing in the Observer on the eve of the 1966 General Election, Crick outlined that what kept him a supporter of the party was the broad 'coalition' Labour represented in terms of interests, doctrines, occupations and classes. The Labour Party's 'complicated and characterful' nature meant that it was reflective of the outside world and unlikely to be captured by a single faction (Crick 1966), in short, the type of pluralism and diversity he considered to be essential to politics. As a moderate, Crick was concerned if any group within the party sought to take control. This underscored his criticism of the Bennite left and Tony Benn himself.

From when Benn first became prominent within the party in the late 1960s, Crick was a critic. In the Observer in 1968, he outlined 'Why Benn is Wrong' and drew parallels between Benn and Enoch Powell. Generally considered polar opposites, Crick argued that Benn and Powell had a shared approach to politics. Crick's piece was part of a series of articles on 'Free Societies in Ferment'. Powell had recently given his 'Rivers of Blood Speech' and Crick's reaction was that while Powell 'was within his rights to raise the issue' of immigration policy, he was 'detestably wrong to do so in the way he did' (Crick 1968b). Crick (1973, 237-239) accused Powell of being a 'demagogue', arguing that Powell's critique went against the fundamental truth that the British 'have been at most times a remarkably tolerant people'. What was 'repugnant' about Powell's interventions was his 'deliberate attempt to stir up intolerance'. As so often in his journalism, Crick's moderation manifests itself in a distaste for alarmist political rhetoric. This he saw on the rise on the political right and left during the late 1960s. Crick believed that Benn was responding to the same sense of crisis in his 'intricate outburst' on the need for 'a new popular democracy'. Though Crick accepted that Britain had 'let the pie of parliamentary democracy go flat, cold and stale', it was a thorough reform that democratic renewal could take place. In this way, Crick saw Powell and Benn (and the student radicals) as 'exotic fungi...springing from the crust' of British parliamentary democracy. Despite the claims of Powell and Benn, as well as the student radicals, Britain was not 'faced with any threat of red or black bloody revolution'.

What we see expressed here is Crick's general repudiation of catastrophising. He saw in such pessimism a threat to democracy. In short, if the situation is so dire, then the suspension of democratic norms could be more easily justified. What made such a perspective dangerous was that it added to a general disengagement with politics. He saw, among the intellectuals, an 'apathetic a-politicism' wrestling with a 'delinquent anti-politicism' (Crick 1968b). Both perspectives were corrosive. In suggesting there was some purer form of democracy, Benn and Powell both offered something which was rhetorically attractive but rather dangerous.

His critique of Benn remains highly relevant given Jeremy Corbyn's closeness to Benn and the influence of Benn on other prominent figures such as Yanis Varoufakis. Powell's influence on Thatcherism (Schofield 2012) and popularity among Brexiteers, such as Simon Heffer, and Nigel Farage, keeps his thought alive. Bennism and Powellism live on as do Crick's warnings about them and their style of politics. Their use of simplistic rhetorical devices and the implication that there were straightforward solutions to Britain's problems went against Crick's conception of politics. Politics is, Crick continually stressed, far from easy. While he was highly critical of populist politicians such as Powell and Benn, the very fact that Crick devoted a number of columns to them demonstrates something important. He did not airily dismiss such figures as being unworthy of comment. Similarly, many contemporary academics may find the comment pieces by Brexiteers, Trumpists and Corbynistas shallow and doctrinaire but they are often influential, framing narratives which seep into the public mind. Critiquing such ideas in academic articles was worthwhile but stepping into this sphere was more likely to actually influence public debate. So, though moderation underpinned his views on party politics, he was hardly disinterested. Where his commentary on the Labour Party did differ from that of the more strident commentators was his deep understanding of its history and ethos. As with his commentary on conflict zones, it was born of personal involvement, through his closeness to Blunkett (2012) and the advisory role with Kinnock (Crick 1989a).

\section{Scottish Questions}

After regular visits in 1978, Crick moved to Scotland in 1984, in part to escape what he saw as an increasingly Thatcherite England (Crick 1992a). Writing in 1992, he despaired of the state of his homeland: 'it is not an England I could any longer feel at home in. Personally I'm ever more happy to be in Scotland' (Crick 1992c). He spent his final decades living on the fringes of Edinburgh's New Town. This gave him an interesting position from which to observe the active constitutional debates in Scotland during the 1980s and 1990s. It revealed to him how anglocentric much of British political debate can be. During this period, he became a prominent figure within the Scottish 'media intelligentsia milieu' (Hearn 2000, 81), alongside figures such as Neal Acherson and Joyce McMillan of The Scotsman. He was involved with The Bulletin of Scottish 
Politics and Scottish Affairs, a journal which, like his beloved Political Quarterly, strives to act as a conduit between academia and a general educated public. As always, Crick offered historical perspective and academic insight to these debates. As a public intellectual, Crick would, in his words, 'inadequately fill' his late friend John Mackintosh's column in the Scotsman with 'analyses and polemics' (Crick 1988a, 1988b, 60). Though he did not complete his final book on The Four Nations, his lectures (Crick 2008), newspaper and magazine articles of this period were part of the working through of its themes: the constitution, Britishness, sovereignty and Scottish independence. The pieces he chiselled out during this period point to the present constitutional tensions.

Again, Crick was not just an observer and he soon became involved in Scottish politics. Given his early work on parliamentary reform, it was natural that he would get involved both in debates about devolution but also about the character of the new Scottish Parliament (Crick and Millar 1995). As we saw with his involvement in Labour Party debates, he believed that PR should be part of any Scottish Parliament. He hoped that the Scottish parliament 'could be a model for a comprehensive reform of the United Kingdom constitution' which he hoped a future Labour government would carry out (Crick 1990b).

Crick saw what was happening in Scotland as a portend of what might happen to the UK more generally. In 1990, he felt that 'Scotland is approaching a political crisis that could affect the whole Constitution of the United Kingdom'. He was particularly critical of the 'new breed' of Conservatives with 'no sense of history'. Their refusal to get involved with the cross-party Scottish Constitutional Convention spoke of a neglect of history and was likely to breed further seperatist feeling. The Conservatives in Scotland were not helping to uphold a central tenet of British Conservatism-keeping the UK together. This lack of care seems even more evident today with a Tory-directed Brexit posing a very serious threat to the survival of the UK. Crick also foresaw the problems Labour would have in 'keeping nationalism as constitutional nationalism' and preventing it becoming separatism (Crick 1990a). Crick's own increasing sympathy for the SNP was again expressed in 'moderate' terms, claiming that both sides of the independence argument were engaged in exaggeration. As Scotland faces the real possibility of 'Indy Ref 2', it may be difficult to cool the rhetoric of the two increasingly entrenched positions. Crick's articles on Scottish politics were the product of a serious engagement with Scottish political figures and intellectuals, including members of the commentariat.

\section{Campus Politics}

Another area where Crick's truculent moderation was on display was in his commentary on university politics. He engaged in this not just as an academic with responsibility for students but also as an observer of political movements and ideas. In his contribution to these debates, he outlined one of his key themes, namely, that extremists rather rely on each other and a 'sense in which the relationship is reciprocal'. In terms of contemporary debates, the culture warriors on the hard right need the left wing radicals and vice versa. In the case of the student revolt of the late 1960s, both sides saw the battle as a microcosm of a deeper social conflict. To the university establishment, the 'revolting students' provided a preview of a society of permissive social attitudes and revolutionary political tendencies. For the student revolutionaries, when they fought the university, they were confronting a reactionary order in league with the military-industrial complex. Much of the commentary on the student revolt at the time was immoderate in the extreme. On occasions, Crick echoed some of the criticisms made by the conservative critics of the student movement. However, he believed that they inflamed the situation by giving the wilder student leaders too much credence: 'as so often in history, revolutionaries and reactionaries thrive on a mutual exaggeration of each others' powers' (Crick 1969). Crick was certainly of the view that the student 'unrest' at the LSE and elsewhere was over-dramatised, on both sides (Crick 1982a), not least by some academics (Crick 1999).

His general attitude was that student radicalism was an overblown phenomenon and that students in general should not all be tarred with this brush. He considered the term 'student extremist' to be highly misleading in that it carried the 'naughty implication that the extremist exemplifies what is latent in all students'. Instead the 'extremist' was 'more likely to be way-out, isolated and-however righteous-on his own' (Crick 1989b). In his introduction to a collection of essays on Student Unrest, he noted that there was 'a danger' that 'in examining extremes, one exaggerates their importance' (Crick 1970, x). There is, Crick (1982a, 135) suggested, 'almost nothing that cando less harm or good to man or beast, or which has less political power, than students' politics'. This exaggeration is strongly evident in contemporary debates on 'cancel culture', where a lot of credence is given to the outbursts of unrepresentative figures.

A particular bugbear of Crick's was the radical students' tendency to connect their legitimate grievances regarding the internal operation of the universities to external matters (Vietnam, Apartheid South Africa, etc.). Crick considered the view that university students were an oppressed group 
distasteful and also counter-productive. He believed that, with their 'absurd demands', the radical students had 'delayed university reform by sweeping away the concern for practical middle term objectives' (Crick 1969). For Crick, this form of student politics was 'the politics of affirmation and the striking of simple attitudes to every world issue' (Crick 1967). Here Crick gives a foretaste of perceived 'virtue signalling' on the contemporary campus. There was nothing wrong with young people taking an interest in international matters, but Crick was clear that it should not interfere with their status as students. Those interested in politics should join or form a political party - that is where they should go to get their political education (Crick 1982a).

Regarding the contemporary 'culture war' on campus, I'd suggest that he'd repeat his maxim, drawn from Orwell that extremists on both sides need each other. The hard right argues that 'the radical left' are spreading a cancer through our politics and institutions. They are mirrored by the radical left who believe they are slaying great injustices through online campaigns and campus demonstrations. Crick would have rejected such catastrophising and would have seen both as a symptom of deep-seated problems in our politics but neither as offering a solution. He would have seen it partly as a re-run of the clashes between the student radicals and the 'catastrophe men' of the right in the 1970s who were 'preaching (like inverted Marxists) that the whole system will collapse if their nostrums are not adopted' (Crick 1978). As a result, Crick (1990c, 212) suggested that 'catastropharians and revolutionaries should be locked up together and denied bail: they panic the public and prevent cool thinking'. Crick's political journalism is therefore worth revisiting for its relevance to contemporary debates. There are other reasons why we should revisit his work, including the model he provides (Gamble 2004a).

\section{Taking the Commentariat Seriously}

As we have seen, Crick's enthusiasm for writing political journalism was in part due to his natural flair for the genre and his less than vain character. He was also gripped by a passionate desire to see academic insights 'translated' into public conversation and, as a consequence, public discourse to improve. His involvement in this world was also a recognition of the pivotal role played by the commentariat in our politics. It is the way in which serious arguments enter the public bloodstream. When members of the public contribute to debates and use social media, they often use rhetorical 'talking points' and narratives which often derive from members of the commentariat. Terms such as 'cancel culture', 'wokeism' and 'the liberal elite' have become part of our discourse due to the popularising efforts of the commentariat.
The vital role played by 'political intellectuals' in formulating and promoting 'ideological narratives' has been reflected in scholarship. However, much of this work has understandably been focussed on those considered 'serious' thinkers and to the impact of think tanks on the "climate of opinion'. What has often been overlooked by students of intellectuals and of political ideas is what Stapleton (2007) refers to as the 'intellectual low life', in essence those not 'serious' enough to be considered 'proper' intellectuals but prominent public voices in what Hearn $(2000,81)$ aptly terms the 'intelligentsia-media milieu'. In his introduction to a 1963 collection of opinion pieces by a range of media commentators, Thomas $(1963,2)$ suggests that this group had now become a 'recognised force in shaping thoughtful opinion'. Their influence derives partly from the vigorous way they communicate their ideas and their polemical style. Such 'professional controversialists' play an important role in reflecting and shaping the 'climate of opinion'.

Most students of political ideas and ideologies generally have a background in political theory, a field which prizes consistency, sophistication and originality. Such standards are not wholly appropriate for such commentators. They should be examined in terms of how and who they have influenced and not necessarily whether their thought is itself deep or convincing. History is littered with influential 'bad' ideas. Overlooking these commentators is misguided as many of them have been conduits for the arguments of serious thinkers-the way in which arguments and narratives enter the political bloodstream. In an essay much praised by Crick, Garnett (1993) argued that the significance of the 'theoretical polemic' had been underestimated. Crick (1988b) himself talked of the 'populist intellectuals' in the media who were key in promoting Thatcherite ideas. The seriousness with which Crick, as a prominent academic, treated his political journalism should be one of his important legacies. It is a legacy taken forward by a number of those influenced by Crick, such as Andrew Gamble (2019). Even more than Crick, Gamble has been capable of communicating profound ideas, drawn from scholarship, in clear English-as witnessed by recent essays in Prospect. Gamble has also, unlike Crick, remained prominent in academia and unalienated from it. This suggests that though the 'tragic chasm' is wide (and possibly widening), it is not unbridgeable.

Returning to Crick's (1981) rhetorical question I began with ('Who reads the newspapers for political thought?'). Good thinking can indeed be found due to the efforts of some of the more thoughtful political commentators and those academics who have entered the public sphere. However, they are generally drowned out by whole phalanxes of commentators distributing the plausible simlpicities that so concerned Crick. There is much of the commentariat which simply regurgitates already established narratives and "talking 
points'. Crick himself, writing in 1974, bemoaned the media coverage of politics and the 'manic regurgitation of tired slogans and evergreen recriminations' (Crick 1974b). As so often with Crick's articles written decades ago, there is little need to emphasise the contemporary relevance of this.

Crick frequently went against the tide but not for the sake of being a contrarian. His truculent moderation is just the sort of voice we need at this time of hyper-partisanship and often shallow political commentary. Crick would have chuntered about the state of political debate but he would not have despaired. The populist wave has re-emphasised the need for a determined defence of politics. Crick believed that simplistic political commentary helps give rise to populist sentiment, a 'politics of arousal more than of reason' and a 'politics of of diversion from serious concerns' (Crick 2003, 90). This makes clear the need for academics, as part of their democratic duty, to more fully engage with combating plausible simplicities in the ever growing opinion space.

Acknowledgements I would like to thank Matthew Flinders and Lord (David) Blunkett for their encouragement with this piece and their comments on an initial draft. Daniel Gordon and an anonymous referee made a number of perceptive and constructive comments on an earlier version. Thanks also to Alexander T. Smith for illuminating discussions on the theme of moderation in politics and to Andrew Gamble for encouraging my initial interest in Crick's work.

\section{References}

Amis, K. (ed) (1977) Harold's Years (London: Quartet).

Annan, N. (1981) Artist in Politics, The New York Review of Books, April 16th.

Ball. S. (ed) (2015) Defending Politics: Bernard Crick at The Political Quarterly Wiley-Blackwell.

Blunkett, D. (2012) Politics as theory and politics as practice, Political Quarterly, Vol. 83, Issue 4, pp 645-652.

Collini, S. (2006) Absent Minds: Intellectuals in Britain (Oxford University Press).

Crick, B. (1962) In Defence of Politics (London: Weidenfeld \& Nicolson).

Crick, B. (1966) The steady wind of domestic change, Observer, March 13th.

Crick, B. (1967) Student politics and violence, Observer, February 5th.

Crick, B. (1968a) The Reform of Parliament, 2nd Edition (London: Weidenfeld and Nicolson).

Crick, B. (1968b) Why Benn is Wrong, Observer, June 2nd.

Crick, B. (1969) To Hell with 'the Students', The Guardian, October 24th.

Crick, B. (1970) A Time to Reason, in Crick, B. \& Robson, W. (eds) Protest and Discontent (Harmondsworth: Penguin).

Crick, B. (1973) Political Theory and Practice (London: Allen Lane).

Crick. B. (1974a) Hayek and the dethronement of politics, The Guardian, April 26th.

Crick, B. (1974b) Treat people as grown-ups, Observer, September 22nd.

Crick, B. (1978) The Right's catastrophe, The Guardian, April 13th.

Crick, B. (1980) George Orwell: A Life (London: Secker \& Warburg).
Crick, B. (1981) The Labour left, London Review of Books, Vol. 3 No. 1 , January 22nd.

Crick, B. (1982a) In Defence of Politics (2nd Edition) (Harmondsworth: Penguin).

Crick. B. (1982b) War, the breakdown of politics, letter to the Editor, The Times, May 6 th.

Crick, B. (1988a) 'Them and Us': Public Impotence and Government Power, in John Morgan, W. (ed) Politics and Consensus in Modern Britain (London: Macmillan).

Crick, B. (1988b) The Rediscovery of English Democratic Socialism, Government and Opposition, Vol. 23 , Issue 4, pp424 - 439.

Crick, B. (1989a) High time to talk about pacts, Observer, March 5th.

Crick, B. (1989b) Essays on Politics and Literature (Edinburgh University Press).

Crick, B (1990a) The growing threat from Scotland, The Guardian, March 4th 1990.

Crick, B. (1990b) How Scotland can set the example, The Guardian, May 3rd.

Crick, B. (1990c) Political Thoughts and Polemics (Edinburgh University Press).

Crick, B. (1991) Pretoria's pain and progress, The Guardian, December 4th.

Crick, B. (1992a) Split loyalties, divided lives, The Independent, February 16 th.

Crick, B. (1992b) Politics and the English Language, The Guardian, March 29th.

Crick, B. (1992c) In defence of compromise, The Guardian, April 13th.

Crick, B. (1995a) Publish or perish, New Statesman \& Society, January 27 th.

Crick, B. (1995b) Implications of publishing leaked document on Ireland, letter to the Editor, The Times, February 3rd.

Crick, B. (1996) I've nearly had it with New Labour, Observer, November 17 th.

Crick, B. (1997) Weary of war and dying for peace, The Herald, September $23 \mathrm{rd}$

Crick, B. (1999). Max Beloff: Loose and Loud Cannon. The Guardian. March 25th.

Crick, B. (2000a) Essays on Citizenship (London: Continuum).

Crick, B. (2000b) Big Brother belittled, The Guardian, August 19th.

Crick, B. (2001) Crossing Borders (Edinburgh University Press).

Crick, B (2003) Democracy: A Very Short Introduction (Oxford University Press).

Crick, B. (2005) Populism, Politics and Democracy, Democratization, Vol.12, No.5, pp.625-632.

Crick, B. (2008) The Four Nations: Interrelations, The Political Quarterly, Vol. 79, No. 1, pp71-79.

Crick, B. \& Millar, D. (1995) To Make the Scottish Parliament a Model for Democracy (Edinburgh: John Wheatley Centre).

D’Ancona, M. (2017) Post-Truth (London: Penguin).

Ferguson, N. (1999) On Media Dons, in Glover, s. (ed) Secrets of the Press (London: Penguin).

Flinders, M. (2012) Defending Politics (Oxford: Oxford University Press)

Flinders, M. (2013) The Tyranny of Relevance and the Art of Translation, Political Studies Review, Vol 11, No. 2, pp149-167.

Gamble, A. (2004a) Public Intellectuals and the Public Domain, New Formations, No. 53, pp41-53

Gamble, A. (2004b) Bernard Crick 1929-, in Levenson, E, Lodge, G \& Rosen, G. (eds) Fabian Thinkers (London: Fabian Society).

Gamble, A. (2008) Intellectually tolerant, never, The Guardian, December 19th.

Gamble, A. (2019) Politics: Why It Matters (Cambridge: Polity).

Gellner, E. (1990) La trahison de la trahison des clercs, in Maclean, I, Montefiore, A \& Winch, P. (eds) The Political Responsibility of Intellectuals (Cambridge University Press). 
Garnett, M (1993) An unheard voice in the squabbles of mankind, Political Quarterly, 64, 336-343.

Grant, W. (2010) The Development of a Discipline (Oxford: John Wiley).

Hampsher-Monk, I. (ed) (1993) Defending politics: Bernard Crick and Pluralism (London: British Academic Press).

Hearn, J. (2000) Claiming Scotland (Edinburgh: Polygon).

Hennessy, P. (1974) Bernard Crick: a pretty potent piece of artillery letting fly in all directions, The Times Higher Education Supplement, November 29th

Hoggart, R. (2004) Mass Media in a Mass Society (London: Continuum),

Jacobs, R.N. and Townsley, E. (2011)The Space of Opinion: Media Intellectuals and the Public Sphere (New York: Oxford University Press).

Jeffrey, C. (2009) Citizen Crick: Politics as Theory and Practice, Scottish Affairs, No. 67, pp1-6

Kenny, M. (2006) History and Dissent: Bernard Crick's The American Science of Politics, American Political Science Review, Vol. 100, No. 4, November, pp547-553.

Kingston, P. (1996) Celebrity Scholars: No. 25 Bernard Crick, The Guardian, July 2nd.

Lavazza, A., \& Farina, M. (2020). The Role of Experts in the Covid-19 Pandemic and the Limits of Their Epistemic Authority in Democracy. Frontiers in Public Health, Vol. 8.

Lloyd, J. (2004) What the Media are Doing to our Politics (London: Constable).

Muggeridge, M. (1966) Tread Softly For You Tread on My Jokes (London: Collins).

O'Brien, J. (2020) How Not To Be Wrong (London: Ebury).

Sandel, M. (2012) What Money Can't Buy: The Moral Limits of Markets (New York: Farrar, Status and Giroux).
Schofield, C. (2012) A nation or no nation? Enoch Powell and Thatcherism, in Jackson, B. \& Saunders, R. (eds.) Making Thatcher's Britain (Cambridge University Press).

Seyd, P. (2008) 'Sir Bernard Crick: a man of kindness, energy and academic rigour', The Guardian, December 19th.

Small, H. (ed) (2002) The Public Intellectual (Oxford: Blackwell).

Smith, A. T. \& Holmwood, J. (eds) (2013) Sociologies of Moderation (Oxford: John Wiley).

Stapleton, J. (2007) British Intellectuals: Identity, Diversity and Change, Twentieth Century British History, Vol. 18, No. 3, pp391-397.

Stoker, Gerry (2006) Why politics matters: making democracy work (Basingstoke: Palgrave Macmillan).

Taylor, C. Politics, Poetry and Pilgrimage, in Hampsher-Monk, I. (ed) (1993) Defending politics: Bernard Crick and Pluralism (London: British Academic Press)

Thomas, D. (ed) (1963) Personal Opinions (London: Thomas Nelson).

Turner, S. (2001) What is the Problem with Experts?, Social Studies of Science, Vol. 31; pp123-149.

Walker, G. (2017) A place apart? The interventions of John P. Mackintosh and Bernard Crick in Northern Ireland, Contemporary British History, 31:4, 593-610.

Publisher's Note Springer Nature remains neutral with regard to jurisdictional claims in published maps and institutional affiliations.

Charlie Ellis is a researcher and EFL teacher based in Edinburgh, UK. $\mathrm{He}$ is currently working on a book on British Conservatism for Edinburgh University Press. 